\title{
Bioactivity of volatile organic compounds by Aureobasidium species against gray mold of tomato and table grape
}

\author{
A. Di Francesco ${ }^{1,2}$ - J. Zajc ${ }^{3,4} \cdot$ N. Gunde-Cimerman ${ }^{4} \cdot$ E. Aprea $^{5,6} \cdot$ F. Gasperi $^{5,6} \cdot$ N. Placi $^{2} \cdot$ F. Caruso $^{2} \cdot$ E. Baraldi $^{1,2}$
}

Received: 21 July 2020 / Accepted: 8 October 2020 / Published online: 17 October 2020

(C) The Author(s) 2020

\begin{abstract}
Aureobasidium strains isolated from diverse unconventional environments belonging to the species A. pullulans, A. melanogenum, and A. subglaciale were evaluated for Volatile Organic Compounds (VOCs) production as a part of their modes of action against Botrytis cinerea of tomato and table grape. By in vitro assay, VOCs generated by the antagonists belonging to the species A. subglaciale showed the highest inhibition percentage of the pathogen mycelial growth (65.4\%). In vivo tests were conducted with tomatoes and grapes artificially inoculated with B. cinerea conidial suspension, and exposed to VOCs emitted by the most efficient antagonists of each species (AP1, AM10, AS14) showing that VOCs of AP1 (A. pullulans) reduced the incidence by $67 \%$, partially confirmed by the in vitro results. Conversely, on table grape, VOCs produced by all the strains did not control the fungal incidence but were only reducing the infection severity $(<44.4 \%$ by A. pullulans; $<30.5 \%$ by $A$. melanogenum, and A. subglaciale). Solid-phase microextraction (SPME) and subsequent gas chromatography coupled to mass spectrometry identified ethanol, 3-methyl-1-butanol, 2-methyl-1-propanol as the most produced VOCs. However, there were differences in the amounts of produced VOCs as well as in their repertoire. The $\mathrm{EC}_{50}$ values of VOCs for reduction of mycelial growth of $B$. cinerea uncovered 3-methyl-1-butanol as the most effective compound. The study demonstrated that the production and the efficacy of VOCs by Aureobasidium could be directly related to the specific species and pathosystem and uncovers new possibilities for searching more efficient VOCs producing strains in unconventional habitats other than plants.
\end{abstract}

Keywords Antibiosis $\cdot$ Botrytis cinerea $\cdot$ Postharvest $\cdot$ VOCs

A. Di Francesco

alessand.difrancesc3@unibo.it

1 CRIOF-Department of Agricultural Sciences, University of Bologna, Via Gandolfi, 19, 40057 Cadriano, Bologna, Italy

2 Department of Agricultural and Food Sciences, University of Bologna, Viale Fanin, 42, 40127 Bologna, Italy

3 Plant Protection Department, Agricultural Institute of Slovenia, Hacquetova ulica 17, 1000 Ljubljana, Slovenia

4 Department of Biology, Biotechnical Faculty, University of Ljubljana, Jamnikarjeva 101, 1000 Ljubljana, Slovenia

5 Center Agriculture Food Environment, University of Trento/Fondazione Edmund Mach, 38010 San Michele all'Adige, TN, Italy

6 Research and Innovation Centre, Fondazione Edmund Mach, via Mach 1, 38010 San Michele all' Adige, Trento, Italy

\section{Introduction}

Aureobasidium pullulans (de Bary) is a highly adaptable polymorphic species characterized by great phenotypic plasticity and ubiquitous ecology. The species complex comprised four varieties until the large genomic differences and substantial physiological differences prompted the separation into four separate species: A. pullulans, A. melanogenum, A. subglaciale, and $A$. namibiae. These species display different patterns of melanisation, different temperature growth limits and salt tolerance (Gostinčar et al. 2014), various biofilm forming capacity and differences in repertoire of enzymatic activities (Zajc et al. 2019; Zajc et al. 2020). Importantly, the strains linked to human infections and able to grow at $37^{\circ} \mathrm{C}$ all clustered together in a well-defined entity, A. melanogenum, preventing the inclusion of any potentially pathogenic strains in biotechnological applications, including biocontrol. Whit regard to A. namibiae, the species name was based on a single isolate from Namib Desert marble (Zalar et al. 2008), an extreme environment that could represent an 
interesting source for new microorganisms characterized by interesting and new antimicrobial metabolites. On the other hand, the species A. pullulans is recognized as one of the most promising biocontrol agents used in plant protection, in particular against postharvest diseases (Di Francesco et al. 2018; Di Francesco et al. 2020a; Zhang et al. 2010), while A. subglaciale is the least studied species in the field of crop defense, without any recognized biocontrol potential.

Although A. pullulans is mostly found associated with phyllosphere and carposphere of various plants (Bozoudi and Tsaltas 2018), it populates also diverse extreme habitats, from hypersaline water of salterns, glacial ice, polluted water, frozen and salt-preserved food, household surfaces and house dust, synthetic polymers and aviation fuel tanks (Gostinčar et al. 2019). The species A. melanogenum has been isolated mainly from oligotrophic and aqueous environments, while psychrotolerant $A$. subglaciale, able to grows at $4{ }^{\circ} \mathrm{C}$, occurs mainly in glacial habitats (Gostinčar et al. 2014).

The differences between these species could be also deepened through the study of the mechanisms of action against fungal pathogens. Antibiosis is considered a biological process by which antagonists produce substances that inhibit or kill potential pathogens in close proximity (Di Francesco et al. 2015). Antibiosis can occur via volatile, low-molecular weight carbon-based organic compounds, derived from a biosynthetic pathway (Gotor-Vila et al. 2017). Many Volatile Organic Compounds (VOCs) show a fungistatic activity, in particular against postharvest fungal diseases of fruit (Di Francesco et al. 2015; Gotor-Vila et al. 2017). Identification of active secondary VOCs metabolites enables their use in process-defined biofumigation or in active packaging, where there is no direct contact between BCAs and the pathogens on food (Di Francesco et al. 2015).

Since volatile metabolites that inhibit the growth of fungal pathogens can also influence fruit/food matrix odor, taste, color, and texture, it is necessary to identify individual components. The solid-phase microextraction (SPME) coupled to GC-MS is an established method for extraction and identification of specific fungal VOCs. Fungal VOCs identified so far with SPME-GC-MS mainly belong to the alcohol class (Di Francesco et al. 2015), to the esters (Fialho et al. 2010), and aldehydes (Buzzini et al. 2003).

Aureobasidium pullulans is known to produce VOCs active against postharvest pathogens such as Monilinia spp. and Botrytis cinerea (Di Francesco et al. 2015, 2020a), at moderate concentrations, making them extremely attractive for postharvest diseases management. Nevertheless, until now no studies were conducted to uncover potential differences in volatilomes of different species of the former $A$. pullulans complex.

Thus, the objectives of the present study were (i) to characterize the main VOCs produced by A. pullulans, $A$. subglaciale, and A. melanogenum with the SPME/GC-MS; (ii) to evaluate the effectiveness of volatile metabolites produced by Aureobasidium spp. against $B$. cinerea by in vitro and in vivo assays; and (iii) to test the antifungal effect of pure main compounds of the selected volatiles on target pathogen in in vitro experiments.

\section{Materials and methods}

\section{Aureobasidium strains}

Aureobasidium strains reported in Table 1 were obtained from the Ex Culture Collection of the Infrastructural Centre Mycosmo (Department of Biology, Biotechnical Faculty, University of Ljubljana, Ljubljana, Slovenia), and the Westerdijk Fungal Biodiversity Institute (Utrecht, The Netherlands) and used for the present experiments. Strains were maintained on nutrient yeast dextrose agar (NYDA: $8 \mathrm{~g} \mathrm{~L}^{-1}$ of nutrient broth, $5 \mathrm{~g} \mathrm{~L}^{-1}$ of yeast extract, $10 \mathrm{~g} \mathrm{~L}^{-1}$ of dextrose and $15 \mathrm{~g} \mathrm{~L}^{-1}$ of technical agar, Oxoid, Basingstoke, UK) and stored at $4{ }^{\circ} \mathrm{C}$ until use. Two days before the experiments, each antagonist was grown on NYDA at $25^{\circ} \mathrm{C}$, and yeast cells were resuspended in sterile distilled water containing $0.05 \%$ (v/v) Tween-80 (Sigma-Aldrich, St. Louis, MO, USA) then adjusted to a final concentration of $10^{8}$ Colony Forming Unit (CFU) $\mathrm{mL}^{-1}$ (Di Francesco et al. 2017).

\section{Pathogen}

The isolate of $B$. cinerea $(\mathrm{Bc} 1)$, originally isolated from a rotted peach, belongs to CRIOF-DipSA collection. The isolate was grown on agar $\left(60 \mathrm{~g} \mathrm{~L}^{-1}\right.$ of oat meal, $10 \mathrm{~g} \mathrm{~L}^{-1}$ of sodium nitrate, $30 \mathrm{~g} \mathrm{~L}^{-1}$ of sucrose, $12 \mathrm{~g} \mathrm{~L}^{-1}$ of agar) and incubated at $25{ }^{\circ} \mathrm{C}$ for 10 days and verified for its virulence on tomato and grape. Pathogen conidia were collected and suspended in sterile distilled water containing $0.05 \%(\mathrm{v} / \mathrm{v})$ Tween 80 and the suspension was adjusted to $10^{5}$ conidia $\mathrm{mL}^{-1}$, by counting the conidia under the microscope by using a haemocytometer (Di Francesco et al. 2020b).

\section{Tomato and table grape}

Tomatoes $c v$ "Datterini" (Solanum lycopersicum, L.) were harvested from an organic orchard located in Cesena (Italy) at commercial maturity and were immediately used.

Table grapes $c v$ 'Vittoria' were harvested in experimental orchards of Bologna University located in Altedo (Bologna-

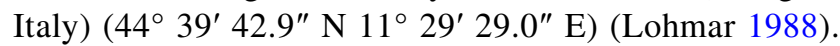
After harvest, fruits with no visible wounds and rots, homogenous in size and quality (soluble solid content, hardness, color), were disinfected by $1 \mathrm{~min}$ immersion in hypochlorite 
Table 1 List of strains used in this study

\begin{tabular}{|c|c|c|c|c|}
\hline Species & Culture collection strain number & $\begin{array}{l}\text { Present } \\
\text { study } \\
\text { number }\end{array}$ & Isolation habitat & Sampling site location \\
\hline \multirow[t]{5}{*}{ Aureobasidium pullulans } & EXF-6519 & AP1 & Felt of a metal roof tile & Slovenia (Mengeš) \\
\hline & EXF-10507 & AP2 & Marble block surface & Italy (Messina) \\
\hline & EXF-10629 & AP3 & Car petrol reservoir & Slovenia (Jezero) \\
\hline & EXF-10650 & $\mathrm{AP} 4$ & Acrylic painting & Slovenia (Solkan) \\
\hline & EXF-10751 & AP5 & Cloud water & France \\
\hline \multirow[t]{5}{*}{ Aureobasidium melanogenum } & EXF-3378/CBS 110374 & AM6 & Public fountain & Thailand \\
\hline & EXF-3397 & AM7 & Endoperitoneal fluid & Greece \\
\hline & EXF-8016 & AM8 & $\begin{array}{l}\text { Bathroom, between faucet and } \\
\text { sink }\end{array}$ & nd \\
\hline & EXF-8429 & AM9 & Tap water & Slovenia \\
\hline & EXF-11028 & AM10 & Proteus anguinus aquarium water & Slovenia, Ljubljana \\
\hline \multirow[t]{5}{*}{ Aureobasidium subglaciale } & EXF-2481/CBS 123387 & AS11 & Subglacial ice & Arctic; Svalbard, Ny Alesund \\
\hline & EXF-4632 & AS12 & $\begin{array}{l}\text { From decaying leaves of Conval- } \\
\text { laria }\end{array}$ & Slovenia \\
\hline & EXF-2425 & AS13 & Subglacial ice & Arctic; Svalbard, Ny Alesund \\
\hline & EXF-2428 & AS14 & Subglacial ice & Arctic; Svalbard, Ny Alesund \\
\hline & EXF-2450 & AS15 & Glacial ice & Arctic; Svalbard, Ny Alesund \\
\hline
\end{tabular}

$0.1 \%(w / v)$, rinsed with tap water and air dried at room temperature. Soon after disinfection, fruits were wounded with a sterile nail $(3 \times 3 \times 3 \mathrm{~mm})$ on the equator (one wound per fruit) and inoculated with pathogen conidial suspension (15 $\mu \mathrm{L})$.

\section{Volatile organic compounds analysis}

VOCs analysis was carried out by using SPME/GC-MS. Glass vials containing $10 \mathrm{~mL}$ of NYDA were inoculated with $100 \mu \mathrm{L}$ of each yeast strain suspension $\left(10^{8} \mathrm{CFU} \mathrm{mL}^{-1}\right)$, and the media alone represented the blank reference. Vials were incubated at $25^{\circ} \mathrm{C}$ for $48 \mathrm{~h}$ and soon after the VOCs were extracted and preconcentrated by solid phase microextraction (SPME) using a $2 \mathrm{~cm}$ PDMS/DVB/CAR fiber (Supelco, Milan, Italy). The fibers were exposed for $30 \mathrm{~min}$, after VOCs were desorbed into the GC injector port for $5 \mathrm{~min}$ at $250{ }^{\circ} \mathrm{C}$. These operations were performed by an automatic system (CTC Analysis AG, Zwingen, Switzerland). The chromatographic separation was performed via an HPInnowax fused-silica capillary column (30 m, $0.32 \mathrm{~mm}$ i.d., $0.5 \mu \mathrm{m}$ film thickness: Agilent Technologies, Santa Clara, California). The GC oven temperature program was as follows: $40{ }^{\circ} \mathrm{C}$ for $3 \mathrm{~min}$, raised from 40 to 220 at $4{ }^{\circ} \mathrm{C} \mathrm{min}{ }^{-1}$, $220{ }^{\circ} \mathrm{C}$ for $1 \mathrm{~min}$, raised from 220 to 250 at $10{ }^{\circ} \mathrm{C} \mathrm{min}{ }^{-1}$ and $250{ }^{\circ} \mathrm{C}$ for $1 \mathrm{~min}$. Helium was used as carrier gas with a constant column flow rate of $1.5 \cdot \mathrm{mL} \mathrm{min}^{-1}$. The transfer line temperature was maintained constant at $220{ }^{\circ} \mathrm{C}$. Upon exiting the column, compounds were ionized via electron impact at $70 \mathrm{eV}$ and detected with a quadrupole mass spectrometer in the range of a mass/charge ratio $(\mathrm{m} / \mathrm{z})$ from 30 to 300 . Chromatograms were processed and analysed by TurboMass v. 5.1 software (Perkin Elmer, Norwalk, CT). Compounds identification was achieved by comparing the spectra with the NIST Standard Reference Database (NIST2014) and by linear retention indices (LRI) calculated under the same chromatographic conditions, injecting C7-C30 n-alkane series (Supelco, Milan, Italy). The relative VOC content of each sample was reported as absolute peak area (Aprea et al. 2012). The sample unit was represented by four vials per each yeast strain and the experiment was conducted once.

\section{In vitro assay}

Effectiveness exerted by VOCs produced by Aureobasidium strains belonging to three different species was assayed by the double Petri dish assay (Di Francesco et al. 2020a). VOCs were tested against mycelium growth of $B$. cinerea and for this purpose, NYDA plates were inoculated by spreading $100 \mu \mathrm{L}$ of each antagonist cell suspension $\left(10^{8} \mathrm{CFU} \mathrm{mL}{ }^{-1}\right)$ incubated at $25^{\circ} \mathrm{C}$ for 2 days. The control consisted of plates without the antagonist. The sample unit was represented by ten plates (replicates) for the control and each Aureobasidium spp. strain. The lid of the plates was replaced by a base plate of MEA (Malt Extract Agar, $50 \mathrm{~g} \mathrm{~L}^{-1}$, Oxoid, UK), inoculated in the middle with a mycelium plug ( $6 \mathrm{~mm}$ of diameter) of the pathogen. The two base plates were sealed with a double layer of Parafilm and incubated at $25^{\circ} \mathrm{C}$ for 5 days. The sample unit was represented by ten plates (replicates) for the control and each 
Aureobasidium strain interaction. The control consisted of plates without the antagonist interaction. The experiment was conducted twice. The inhibition rate of mycelial growth was calculated using the equation (Chen and Dai 2012):

$\%$ of inhibition $=\frac{(\mathrm{d} 1-\mathrm{d} 2)}{\mathrm{d} 1} \times 100$

where (\%) is the percent of inhibition of pathogen mycelial growth; $\mathrm{d} 1$ represents the control colony diameter (mm); $\mathrm{d} 2$ represents the treated colony diameter $(\mathrm{mm})$.

\section{In vivo assays}

The antagonistic activity of VOCs produced by the most efficient Aureobasidium strains of each tested species (AP3, AM10, AS14) was tested for controlling gray mold symptoms in fruits. Tomatoes (20 fruits) and grapes (20 fruits) were placed in sterile glass boxes $(24 \times 18 \times 8 \mathrm{~cm}$, $\mathrm{L} \times \mathrm{W} \times \mathrm{H})$ with a thin layer of NYDA $(120 \mathrm{~mL})$ positioned at the bottom and inoculated by spreading $500 \mu \mathrm{L}$ of each yeast strain suspension $\left(10^{8} \mathrm{CFU} \mathrm{mL}^{-1}\right)$ and incubated at $25^{\circ} \mathrm{C}$ for 2 days. Fruits were positioned on a sterile grid to separate them from the bottom substrate and avoid the direct contact and possible contaminations (Di Francesco et al. 2020a). Each fruit was wounded and inoculated with $15 \mu \mathrm{L}$ of suspension of $B$. cinerea $\left(10^{5}\right.$ conidia $\left.\mathrm{mL}^{-1}\right)$. The boxes were closed with plastic lid and immediately sealed with Parafilm. The control consisted of inoculated fruit placed in boxes without yeast suspensions. The boxes containing inoculated fruit were kept at $20^{\circ} \mathrm{C}$. The percentage of rotten fruits and the lesion diameters were measured after 5 days of incubation. The sample unit was represented by two boxes per each yeast strain. The experiment was conducted twice.

\section{Synthetic volatile organic compound effect on Botrytis cinerea mycelial growth}

Using a microsyringe, pure 3-methyl-1-butanol, 2-methyl1-propanol, and ethanol (Sigma-Aldrich, St. Louis, MO) were placed in quantity of 25,50 , and $100 \mu \mathrm{L}$ on a filter paper (Whatmann No. 1, $90 \mathrm{~mm}$ diameter) positioned inside the cover of a MEA dish previously inoculated in the middle with $6 \mathrm{~mm}$ pathogen mycelial plug. The aliquots of pure compounds introduced in the Petri dishes corresponded to $2.25,1.12$, and $0.56 \mathrm{~mL} \mathrm{~L}^{-1}$ headspace, as described by $\mathrm{Di}$ Francesco et al. (2015). The dishes were immediately closed, sealed with Parafilm and incubated at $25^{\circ} \mathrm{C}$. The activity of each pure compound against mycelial growth was evaluated after 5 days of incubation. In the control, pure compounds were substituted by equivalent amounts of distilled water. Ten plates for each VOC concentration represented the sample unit and the experiment was conducted twice.
$\mathrm{EC}_{50}$ values were calculated as the headspace concentrations $\left(\mathrm{mL} \mathrm{L}^{-1}\right)$ that inhibited pathogen mycelial growth by $50 \%$ compared with the control.

\section{Statistical analysis}

Data were analysed by one-way analysis of variance (ANOVA). Statistical comparison of means was carried out by using Tukey's HSD Test $(\alpha=0.05)$. All analyses were performed with Mini Tab 16 . The $\mathrm{EC}_{50}$ values of each compound were calculated using the probit analysis applied to the percentage of inhibition of the pathogen mycelial growth (Lesaffre and Molenberghs 1991).

\section{Results}

\section{Volatile organic compounds analysis}

The headspace VOCs of Aureobasidium strains were isolated and analyzed by SPME/GC-MS. Absolute peak areas (AA) of detected and identified compounds are shown in Table 2.

Compounds belonging to the class of alcohols dominated production by all the three Aureobasidium species without significant differences between them, in particular ethanol, 3-methyl-1-butanol, and 2-methyl-1-propanol. The identification of these compounds was confirmed by comparison with standards and used for subsequent experiments. Among tested Aureobasidium species only A. melanogenum did not produce butyrolactone, 3-ethylbenzaldehyde, and $\gamma$-cadinene (Table 2). VOCs mainly produced by each strain belong to the species that showed more effectiveness against $B$. cinerea in previous experiments. The A. pullulans strain AP1 displayed a higher activity of target VOCs production with respect to A. melanogenum AM10 and A. subglaciale AS14 strains (Fig. 1) mainly for ethanol and 3-methyl-1-butanol.

\section{In vitro assay}

The antifungal effect of VOCs produced by Aureobasidium strains was tested on B. cinerea by the double Petri dish assay system (Di Francesco et al. 2015), avoiding any physical contact between the yeasts and the pathogen. The VOCs produced by all tested strains significantly inhibited $B$. cinerea mycelial growth, except for the A. pullulans strain AP4 (Fig. 2), indicating variability in the antagonistic activity among strains of $A$. pullulans. Aureobasidium subglaciale showed the highest inhibition percentage of the pathogen mycelial growth (65.4\% on average), with the strains AS11 and AS14 reducing B. cinerea growth by $80 \%$ and $90.2 \%$, respectively. Also A. pullulans AP1 strain showed high effectiveness (72.1\%). On the other hand, the 
Table 2 Analyses of volatile organic compounds (VOCs) produced by Aureobasidium spp. with HS-SMPE and GC-MS

\begin{tabular}{|c|c|c|c|c|}
\hline \multirow[t]{3}{*}{ Compound } & \multirow[t]{3}{*}{ RT } & \multicolumn{3}{|c|}{ Absolute areas (AA). } \\
\hline & & \multicolumn{3}{|c|}{ Aureobasidium spp. } \\
\hline & & Pullulans & Melanogenum & Subglaciale \\
\hline Ethyl acetate & 2.51 & $1.10 \mathrm{E}+06 \mathrm{a}$ & $1.85 \mathrm{E}+06 \mathrm{~b}$ & $4.65 \mathrm{E}+06 \mathrm{c}$ \\
\hline Ethanol & 3.20 & $5.39 \mathrm{E}+08 \mathrm{c}$ & $4.22 \mathrm{E}+08 \mathrm{~b}$ & $3.18 \mathrm{E}+08 \mathrm{a}$ \\
\hline $\begin{array}{l}\text { 2-Methyl-1-pro- } \\
\text { panol }\end{array}$ & 7.33 & $1.66 \mathrm{E}+07 \mathrm{~b}$ & $1.93 \mathrm{E}+07 \mathrm{c}$ & $1.18 \mathrm{E}+07 \mathrm{a}$ \\
\hline Isoamyl acetate & 8.13 & $8.53 \mathrm{E}+04 \mathrm{a}$ & $1.53 \mathrm{E}+05 \mathrm{~b}$ & $9.59 \mathrm{E}+04 \mathrm{a}$ \\
\hline $\begin{array}{l}\text { 3-Methyl-1-bu- } \\
\text { tanol }\end{array}$ & 10.74 & $5.76 \mathrm{E}+07 \mathrm{~b}$ & $7.52 \mathrm{E}+07 \mathrm{c}$ & $3.66 \mathrm{E}+07 \mathrm{a}$ \\
\hline $\begin{array}{l}\text { 2-Methyl-2-bute- } \\
\text { nol }\end{array}$ & 14.05 & $1.07 \mathrm{E}+05 \mathrm{~b}$ & $4.87 \mathrm{E}+04 \mathrm{a}$ & $2.00 \mathrm{E}+05 \mathrm{c}$ \\
\hline Methyl benzoate & 21.86 & $2.79 \mathrm{E}+04 \mathrm{~b}$ & $8.26 \mathrm{E}+03 \mathrm{a}$ & $2.69 \mathrm{E}+04 \mathrm{~b}$ \\
\hline Butyrolactone & 21.97 & $3.96 \mathrm{E}+04 \mathrm{c}$ & $0.00 \mathrm{E}+00 \mathrm{a}$ & $3.21 \mathrm{E}+04 \mathrm{~b}$ \\
\hline $\begin{array}{l}\text { 3-Ethylbenzalde- } \\
\text { hyde }\end{array}$ & 23.85 & $1.32 \mathrm{E}+03 \mathrm{c}$ & $0.00 \mathrm{E}+00 \mathrm{a}$ & $7.66 \mathrm{E}+02 \mathrm{~b}$ \\
\hline$\gamma$-Cadinene & 24.93 & $1.98 \mathrm{E}+02 \mathrm{c}$ & $0.00 \mathrm{E}+00 \mathrm{a}$ & $1.00 \mathrm{E}+02 \mathrm{~b}$ \\
\hline$\alpha$-Phenylethanol & 26.16 & $3.58 \mathrm{E}+03 \mathrm{a}$ & $7.34 \mathrm{E}+03 \mathrm{c}$ & $4.50 \mathrm{E}+03 \mathrm{~b}$ \\
\hline $\begin{array}{l}\text { p-Acetylethylben- } \\
\text { zene }\end{array}$ & 26.55 & $1.21 E+03 c$ & $3.51 \mathrm{E}+02 \mathrm{~b}$ & $0.00 \mathrm{E}+00 \mathrm{a}$ \\
\hline $\begin{array}{l}\text { (Z)-Cinnamalde- } \\
\text { hyde }\end{array}$ & 26.60 & $1.36 \mathrm{E}+02 \mathrm{a}$ & $3.74 \mathrm{E}+02 \mathrm{~b}$ & $4.63 \mathrm{E}+02 \mathrm{c}$ \\
\hline $\begin{array}{l}\text { Ethyl tetrade- } \\
\text { canoate }\end{array}$ & 30.96 & $4.27 \mathrm{E}+04 \mathrm{c}$ & $8.66 \mathrm{E}+03 \mathrm{a}$ & $1.56 \mathrm{E}+04 \mathrm{~b}$ \\
\hline
\end{tabular}

DVB/CAR/PDMS SPME fiber was used. The values represent the average of the same compound produced by 5 strains (each analysed by four vials) that belong to the same species (A. pullulans, A. melanogenum, A. subglaciale). Different letters represent significant differences among the species for each compound according to Tukey's HSD Test $(\alpha=0.05)$

strains belonging to $A$. melanogenum showed low variability of VOCs effect on B. cinerea with an average of $51.9 \%$ of inhibition.

\section{In vivo assays}

The VOCs produced by the most effective strains AP1, AM10, AS14 were tested against B. cinerea on tomato and table grape (Fig. 3a, b). Regarding tomato, the fungal pathogen was better controlled by AP1 (A. pullulans) VOCs, showing $67 \%$ of incidence reduction. Strains AM10 (A. melanogenum) and AS14 (A. subglaciale) reduced fungal incidence of $38.4 \%$ and $49.2 \%$ respectively (Fig. $3 a$ ). On tomato, VOCs produced by the tested antagonist strains blocked the pathogen sporulation. When assayed on table grape, the VOCs of the tested strains did not reduce the fungal incidence which was really high (up to $90 \%$, data not shown) but significantly reduced symptom severity: A. pullulans AP1 for 44.4\%, and both A. melanogenum AM10 and
A. subglaciale AS14 for 30.5\% (Fig. 3b). On grape, VOCs produced by all strains stimulated the fungal sporulation (Fig. 4).

\section{Synthetic volatile compound effect on Botrytis cinerea mycelial growth}

As commented above, the compounds 3-methyl-1-butanol, 2-methyl-1-propanol, and ethanol, which resulted as the main VOCs produced by Aureobasidium spp., were tested for their inhibitory activity on mycelial growth of $B$. cinerea. 3-methyl-1-butanol was the most effective compound, showing the lowest $\mathrm{EC}_{50}$ value $\left(0.09 \mathrm{~mL} \mathrm{~L}^{-1}\right)$. In comparison ethanol and 2-methyl-1-propanol showed the lowest antifungal activity against $B$. cinerea mycelial growth, with $\mathrm{EC}_{50}$ values ranging from 0.20 to $0.51 \mathrm{~mL} \mathrm{~L}^{-1}$, respectively (Table 3). Furthermore, no quality alterations (color, texture, odor) were detected on the VOCs treated fruits (data not reported).

\section{Discussion}

The Aureobasidium pullulans species complex was characterized by high genetic and phenotypic variability. Gostinčar et al. (2014) elevated the varieties of the A. pullulans species to the level of separate and well defined species based on large differences in genomic data together with distinctive ecology and physiology: A. pullulans, A. subglaciale, A. namibiae, and A. melanogenum. As $A$. melanogenum is recognized as opportunistic human pathogen (Gostinčar et al. 2019), it should not be used as a biocontrol agent, while $A$. pullulans is one of the most extensively studied and used biocontrol agents, in particular for postharvest diseases (Di Francesco et al. 2018, 2020a; Zhang et al. 2010). Aureobasidium subglaciale, isolated so far only in some specialized environments and characterised by low temperatures and oligotrophic conditions, was recently proposed to be used in biocontrol of storage fungal diseases (Di Francesco et al. 2020b).

While VOCs production and bioactivity of $A$. pullulans have been studied in the past, no such studies were performed for A. subglaciale or even A. melanogenum. Also, the strains of $A$. pullulans studied and characterized for the biological control against crop diseases, were isolated from plants habitats such as fruit or leaf surfaces (Di Francesco et al. 2018; Mounir et al. 2007). Conversely, the present study considered the possible antagonistic activity of $A$. subglaciale and $A$. melanogenum strains isolated from non-plant related environment. Although such strains may not have been tested with respect to their volatilomes, some of them were tested with respect to the antagonistic activity.

Fourteen out of fifteen strains of the three species produced VOCs that were shown to be active in vitro against 


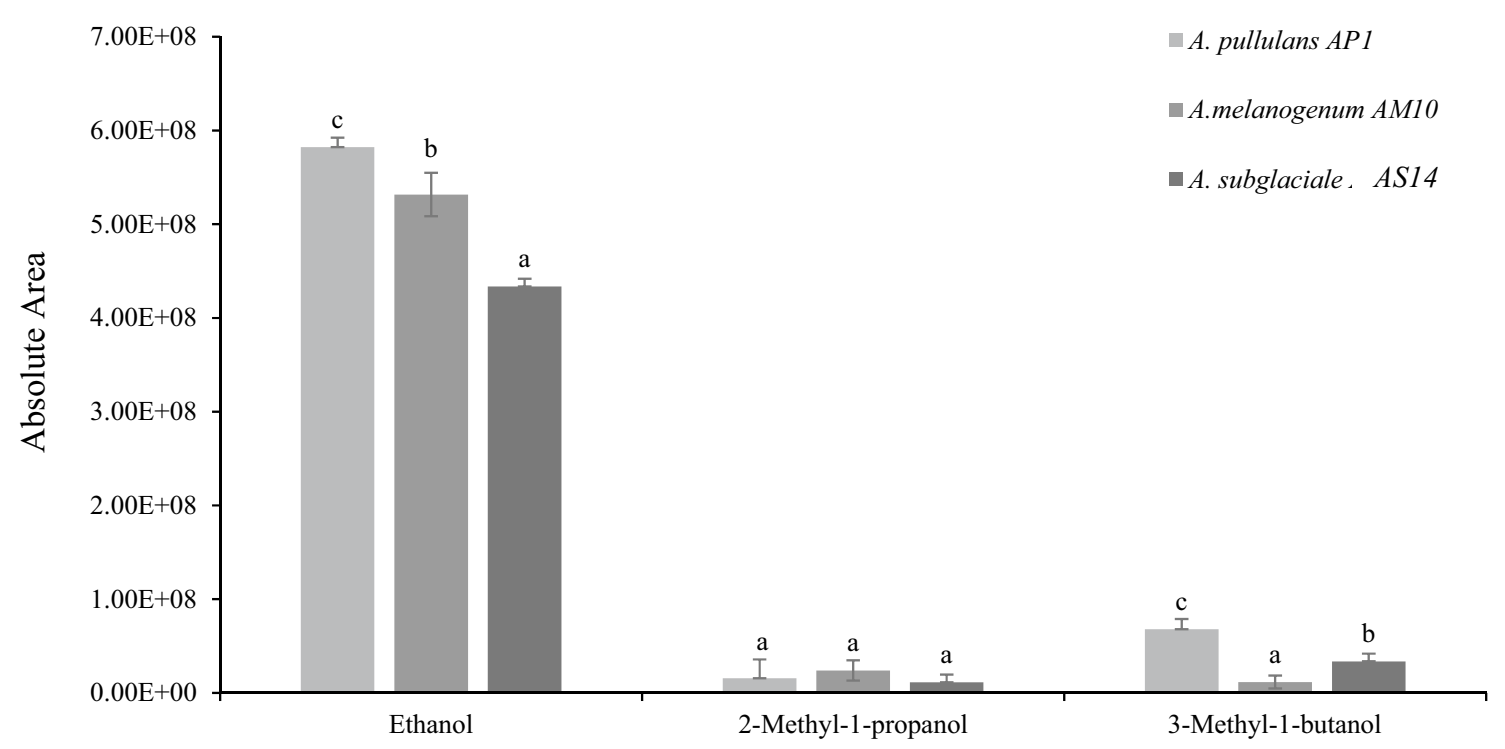

Fig. 1 Principal Volatile Organic Compounds (VOCs) produced by Aureobasidium spp. strains AP1 (A. pullulans), AM10 (A. melanogenum), AS14 (A. subglaciale) and detected with HS-SMPE and GCMS gas phase. DVB/CAR/PDMS SPME fiber was used. Each value is the mean \pm standard deviation of four replicates for each strain. Different letters indicate significant differences according to Tukey's HSD Test $(\alpha=0.05)$

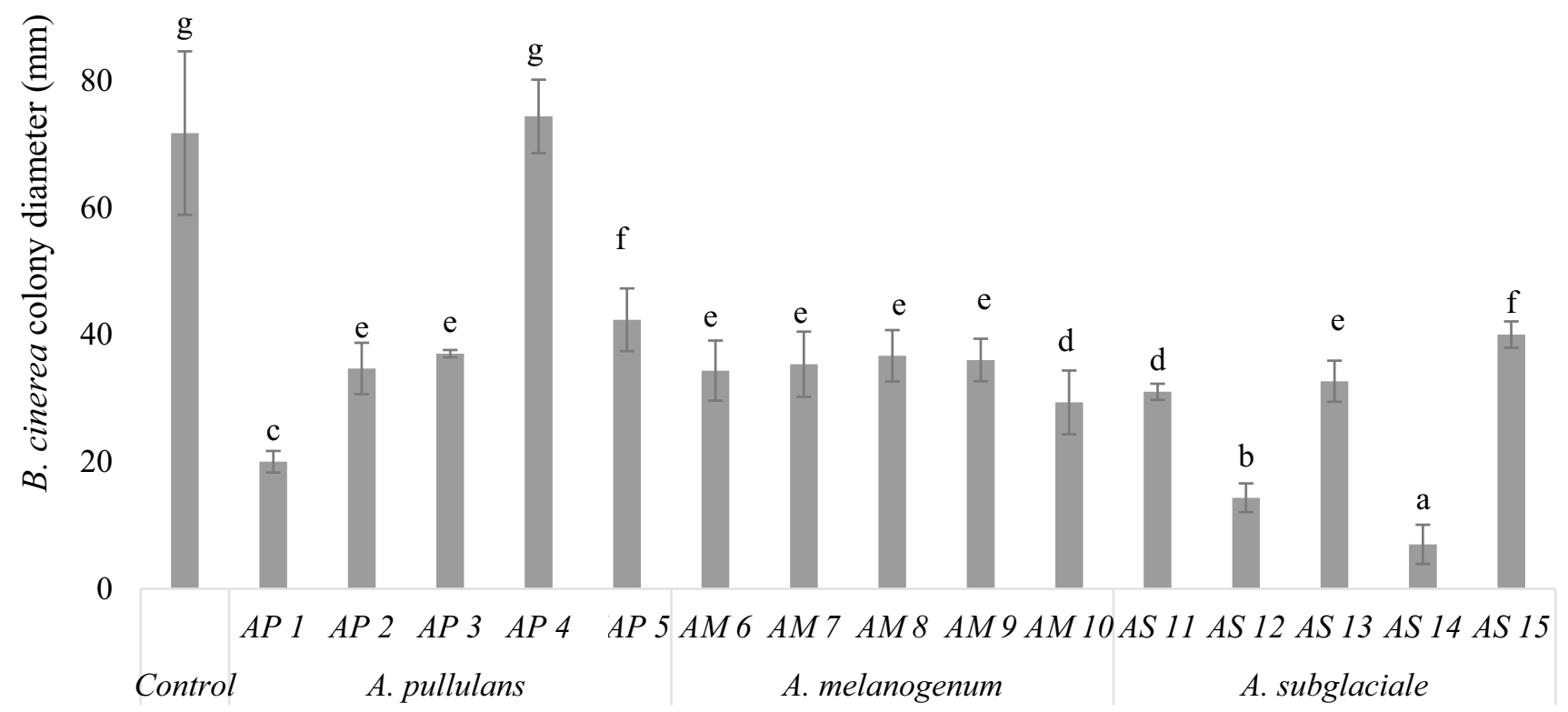

Fig. 2 Effect of volatile compounds produced by Aureobasidium strains belonging to A. pullulans, A. melanogenum, and A. subglaciale species on the mycelial growth $(\mathrm{mm})$ of Botrytis cinerea. Colony diameter $(\mathrm{mm})$ was measured after 5 days at $25^{\circ} \mathrm{C}$. Each value is

the mean of 10 plates (replicates) \pm standard deviation. Different letters represent significant differences among the strains according to Tukey's HSD Test $(\alpha=0.05)$

gray mold by reducing the colony growth of $B$. cinerea. However, there were substantial differences in the effectiveness among the three species and even among individual strains of $A$. pullulans and A. subglaciale. Among

A. subglaciale, the strains AS12 and AS14 reduced growth of $B$. cinerea by $80 \%$ and $92.2 \%$ respectively. Altogether this species showed the highest average inhibition (65.4\%). In the case of A. pullulans, the strain AP1 exhibited $72.1 \%$ 
Fig. 3 In vivo antagonistic effect of VOCs produced by Aureobasidium strains on Botrytis cinerea in tomato (a) (disease incidence-\%) and table grape (b) (disease severity, indicated as the average of two diameter measurements-mm). Fruits were artificially inoculated with $B$. cinerea conidial suspension $\left(10^{5}\right.$ conidia $\left.\mathrm{mL}^{-1}\right)$ and incubated for 5 days at $20{ }^{\circ} \mathrm{C}$ and $85 \% \mathrm{RH}$. Control consisted of NYDA without yeast inoculation. Each value is the mean \pm standard deviation of two replicates of 20 fruit each for tomato and grape, respectively. Different letters represent significant differences among the yeasts VOCs treatments according to Tukey's HSD Test $(\alpha=0.05)$
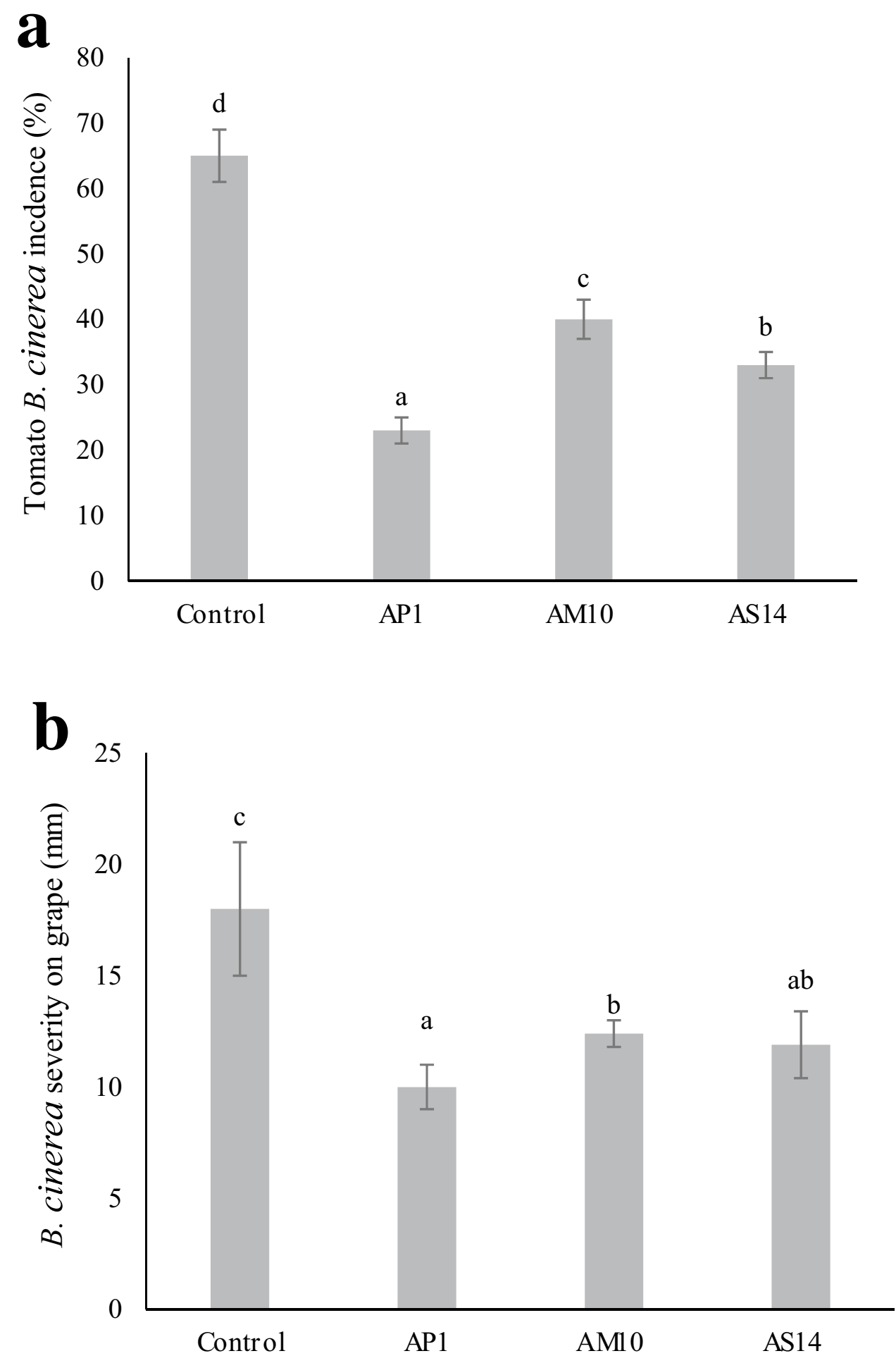

effectiveness, while AP4 did not inhibit at all the growth of $B$. cinerea, indicating a high diversity in efficiency in both A. pullulans and A. subglaciale. On the contrary, different A. melanogenum strains showed similar effects against $B$. cinerea, unregarding their isolation ecology.
Recently, it was shown that strains of A. pullulans, albeit possessing potent antagonistic activity against various plant pathogenic fungi, exhibit substantial differences in aspects linked to the mechanism of action underneath their antagonistic activity, for instance in enzymatic repertoire and the 
Fig. 4 Effect of volatile organic compounds (VOCs) produced by AP1, AM10, AS14 strains, respectively $A$. pullulans, $A$. melanogenum, and $A$. subglaciale, on table grape artificially inoculated with Botrytis cinerea conidial suspension

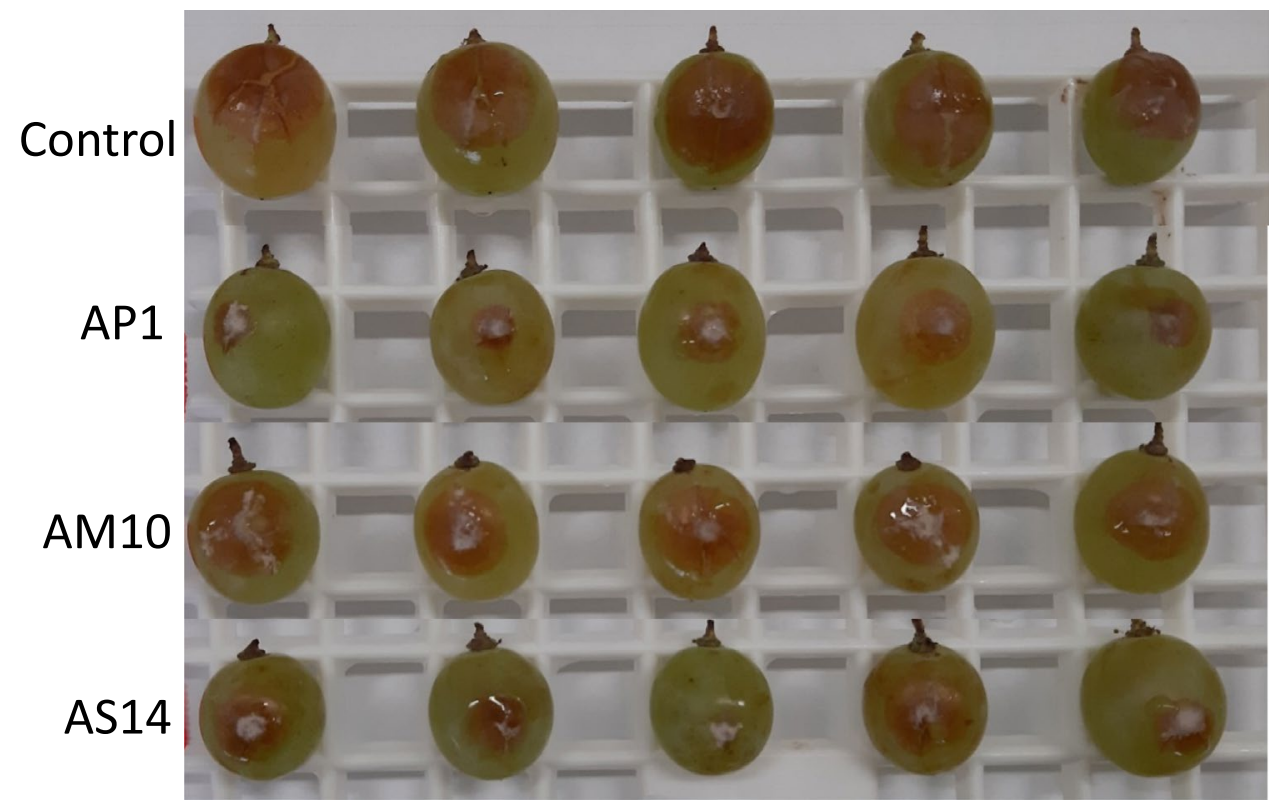

Table $3 \mathrm{EC}_{50}$ values $\left(\mathrm{mL} \mathrm{L}^{-1}\right)$ of synthetic volatile compounds mainly produced by Aureobasidium spp. strains evaluated on mycelial growth $(\varnothing, \mathrm{mm})$ of Botrytis cinerea $(B c 1)$

\begin{tabular}{ll}
\hline & $\begin{array}{l}\mathrm{EC}_{50} \\
\text { values }(\mathrm{mL} \\
\left.\mathrm{L}^{-1}\right)\end{array}$ \\
\hline Ethanol & 0.51 \\
3-Methyl 1 butanol & 0.09 \\
2 Methyl 1 propanol & 0.20 \\
\hline
\end{tabular}

The mycelial growth measurements were carried out after 5 days of incubation at $25^{\circ} \mathrm{C}$

enzymatic activities, siderophore production, and tolerance to stress (Zajc et al. 2020). Strains of A. pullulans used in this study originated from different extreme habitats such as cloud water, roof tile, marble rock surface, painting, and even petrol reservoir. The genome resequencing of fifty strains of A. pullulans from diverse habitats confirmed its generalist nature and homogenous population structure due to high recombination within the species, without any observed specialization to a particular habitat or geographic location (Gostinčar et al. 2019). This suggests that potent antagonistic strains can be found also in habitats not associated with plants.

The best in vitro performing strains (AP1, AM10, and AS14) showed different performances in vivo. Aureobasidium pullulans (AP1) appeared the most effective for controlling $B$. cinerea as it reduced gray mold incidence on tomato and severity on table grape. However, A. subglaciale (AS14) that showed the highest efficacy in reducing $B$. cinerea colony growth in in vitro assay, performed worse than A. pullulans in vivo. This phenomenon is not uncommon and was also observed in various previous studies (Chen et al. 2018). Conversely, Di Francesco et al. (2015) showed how A. pullulans strains L1 and L8 were more effective in the control of $B$. cinerea on apple than in inhibiting fungal conidial germination, displaying a reduction of the pathogen lesion diameter of $88.9 \%$ and $94.4 \%$ respectively. These results confirmed how VOCs produced by different yeast strains, also belonging to the same species, can have a different effect on a target pathogen and host.

Aureobasidium subglaciale has a much more restricted distribution than A. pullulans as it was mainly found in subglacial ice in the Arctics (Zalar et al. 2008), and as epiphyte on moss (Kachalkin 2010). It tolerates high gamma irradiation, UV light, heavy metal ions (Liu et al. 2017), and low growth temperatures (Gostinčar et al. 2014), making it interesting for postharvest biocontrol applications. Mestre et al. showed biocontrol potential of psychrophilic yeasts from Patagonia (Argentina) against some plant pathogens in cold-temperate regions (Mestre et al. 2011) or during low- temperature storage of fruit and vegetables. Our previous study showed its potential in biocontrol via non-volatile compounds (Di Francesco et al. 2020b).

Aureobasidium melanogenum VOCs displayed the lowest effectiveness against $B$. cinerea. However, A. melanogenum was recognized as an opportunistic human pathogen (Gostinčar et al. 2014), so its use in biological control due to the potential health risk is considered inappropriate. Importantly, given that this species was only recently separated from A. pullulans, a phylogenetic analysis of the twenty A. pullulans strains used so far in biocontrol confirmed that only A. pullulans strains (Zajc et al. 2020) were used in extensive postharvest disease control studies (Di Francesco et al. 2018; Parafati et al. 2015). 
Interestingly, our study highlighted that VOCs produced by all tested strains reduced the gray mold severity but at the same time stimulated the B. cinerea sporulation on table grapes. Previous studies reported that dipping the fruits in diluted ethanol solution successfully prevented grey mold on grapes (Dao and Dantigny 2011; Gabler et al. 2004; Lichter et al. 2002; Romanazzi et al. 2007) and also demonstrated that ethanol fumigation controlled grey mold as well as or even better than $\mathrm{SO}_{2}$ (Lurie et al. 2006). The reason for enhanced sporulation of $B$. cinerea in our experimental setup might be in other VOCs than ethanol. A possible explanation could be that some VOCs could stimulate grape ripening, modifying fruit chemical composition and stimulating pathogen sporulation. In fact, as fruit ripen, post-harvest fungal pathogens become more aggressive and quickly colonize fruit tissue (Alkan and Fortes 2015). A possible explanation for the differences in pathogen aggressiveness after the exposure to VOCs on tomato and grapes observed in our study could be related to different physiological characteristics: tomato being climacteric and grape nonclimacteric fruit. This remains to be further investigated. Also, many of these VOCs identified and tested by in vitro assay against pathogens growth can have a different effect with respect to the in vivo tests, where the microorganism is involved in complex interactions with the fruit response, microbiome, and volatilome, as well as the environmental conditions including atmosphere surroundings (Eckert and Ratnayake 1994). In fact, VOCs can play a role in host selectivity of some pathogens. In order to understand the nature of VOCs produced by the different Aureobasidium species, the SPME-GC-MS technique was adopted. Detected VOCs mainly belonged to the alcohols and esters classes, similarly to other A. pullulans strains (Di Francesco et al. 2015). Ethanol, 2-methyl-1-propanol, and 3-methyl-1-butanol were the principal VOCs produced by all the tested strains and in particular by AP1 (A. pullulans), followed by AM10 (A. melanogenum), and AS12 (A. subglaciale). However, based on the $\mathrm{EC}_{50}$ values of each pure synthetic metabolite tested against $B$. cinerea mycelial growth, 3-methyl-1 butanol was the most efficient compound $\left(0.08 \mathrm{~mL} \mathrm{~L}^{-1}\right)$ whereas the most produced and at the same time the least active alcohol was ethanol $\left(0.51 \mathrm{~mL} \mathrm{~L}^{-1}\right)$. A hierarchical clustering of Aureobasidium species based on the types of VOCs, showed that A. pullulans and A. subglaciale cluster closer together, producing more or less the same repertoire of VOCs (data not reported). The only VOC produced by A. pullulans, but not by $A$. subglaciale, was p-acetylethylbenzene. Furthermore, A. pullulans produced higher amounts of 3-ethylbenzaldehyde, $\gamma$-cadinene, and ethyl tetradecanoate than A. subglaciale. These compounds might be responsible for higher effectiveness of $A$. pullulans against $B$. cinerea, but this speculation requires further investigation to be confirmed. Aureobasidium melanogenum produced a high concentration of each detected compounds except for butyrolactone, 3-ethylbenzaldehyde, and $\gamma$-cadinene.

VOCs have many effects that are beneficial, from promoting plant growth to antagonizing plant pathogens. For instance, detected lactones belong to the class of amino compounds containing lipids produced by microorganisms, plant-associated bacteria, and plant growth-promoting rhizobacteria (PGPRs) (Kanchiswamy et al. 2015). Furthermore, benzaldehydes are noted to be antibacterial compounds (Friedman et al. 2003), again suggesting potential antimicrobial activity of VOCs produced by A. pullulans.

In conclusion, VOCs produced by Aurebasidium spp. were effective in suppressing mycelial growth of $B$. cinerea particularly in in vitro assays and partially also in vivo. This study showed that 3-methyl-1-butanol, and 2-methyl-1-propanol are the VOCs used as biocontrol agents produced by Aureobasidium strains, previously reported in other yeasts and endophytic fungi (Mitchell et al. 2010; Strobel et al. 2001). Our study uncovered differences among the three species regarding the amounts of produced VOCs. VOCs dynamic is extremely complex to understand mainly due to their versatile ecology and evolution paths. However, the results showed that the three tested yeast species produced the same VOCs, whit an exception for A. melanogenum volatilome deficient on butyrolactone, 3-ethylbenzaldehyde, and $\gamma$-cadinene volatile compounds.

By representing a bioactive interface between the pathogens and other microorganisms, VOCs are useful for crop protection and sustainable agriculture perspectives (Corcuff et al. 2011). Biofumigation with VOCs opens new possibilities to control postharvest microbial decays of fruits as they avoid physical contact of a biopesticide with the product.

Funding Open access funding provided by Alma Mater Studiorum Università di Bologna within the CRUI-CARE Agreement.

\section{Compliance with ethical standards}

Conflict of interest The authors declare that they have no known competing financial interests or personal relationships that could have appeared to influence the work reported in this paper.

Open Access This article is licensed under a Creative Commons Attribution 4.0 International License, which permits use, sharing, adaptation, distribution and reproduction in any medium or format, as long as you give appropriate credit to the original author(s) and the source, provide a link to the Creative Commons licence, and indicate if changes were made. The images or other third party material in this article are included in the article's Creative Commons licence, unless indicated otherwise in a credit line to the material. If material is not included in the article's Creative Commons licence and your intended use is not permitted by statutory regulation or exceeds the permitted use, you will need to obtain permission directly from the copyright holder. To view a copy of this licence, visit http://creativecommons.org/licenses/by/4.0/. 


\section{References}

Alkan N, Fortes AM (2015) Insights into molecular and metabolic events associated with fruit response to post-harvest fungal pathogens. Front Plant Sci 6:889. https://doi.org/10.3389/ fpls.2015.00889

Aprea E, Corollaro ML, Betta E, Endrizzi I, Dematte' ML, Biasioli F, Gasperi F (2012) Sensory and instrumental profiling of 18 apple cultivars to investigate the relation between perceived quality and odour and flavour. Food Res Int 49:677-686. https://doi. org/10.1016/j.foodres.2012.09.023

Bozoudi T, Tsaltas T (2018) The multiple and versatile roles of Aureobasidium pullulans in the vitivinicultural sector. Fermentation 4:85. https://doi.org/10.3390/fermentation4040085

Buzzini P, Martini A, Cappelli F, Pagnoni UM, Davoli P (2003) A study on volatile organic compounds (VOCs) produced by tropical ascomycetous yeasts. Ant van Leeuw Int J 84:301-311. https ://doi.org/10.1007/s11274-009-0255-4

Chen PH, Chen RY, Chou JY (2018) Screening and evaluation of yeast antagonists for biological control of Botrytis cinerea on strawberry fruits. Mycobiology 46:33-46. https://doi. org/10.1080/12298093.2018.1454013

Chen Y, Dai G (2012) Antifungal activity of plant extracts against Colletotrichum lagenarium, the causal agent of anthracnose in cucumber. J Sci Food Agric 92:1937-1943. https://doi. org/10.1002/jsfa.5565

Corcuff R, Mercier J, Tweddell R, Arul J (2011) Effect of water activity on the production of volatile organic compounds by Muscodor albus and their effect on three pathogens in stored potato. Fungal Biol 115:220-227. https://doi.org/10.1016/j. funbio.2010.12.005

Dao T, Dantigny P (2011) Control of food spoilage fungi by ethanol. Food Control 22:360-368. https://doi.org/10.1016/j.foodc ont.2010.09.019

Di Francesco A, Ugolini L, Lazzeri L, Mari M (2015) Production of volatile organic compounds by Aureobasidium pullulans as a potential mechanism action against postharvest fruit pathogens. Biol Control 81:8-14. https://doi.org/10.1016/j.biocontrol .2014.10.004

Di Francesco A, Milella F, Mari M, Roberti R (2017) A preliminary investigation into Aureobasidium pullulans as a potential biocontrol agent against Phytophthora infestans of tomato. Biol Control 114:144-149. https://doi.org/10.1016/j.biocontrol .2017.08.010

Di Francesco A, Calassanzio M, Ratti C, Folchi A, Baraldi E (2018) Molecular characterization of the two postharvest biological control agents Aureobasidium pullulans L1 and L8. Biol Control 123:53-59. https://doi.org/10.1016/j.biocontrol.2018.05.005

Di Francesco A, Di Foggia M, Baraldi E (2020a) Aureobasidium pullulans volatile organic compounds as alternative postharvest method to control brown rot of stone fruits. Food Microbiol 87:103395. https://doi.org/10.1016/j.fm.2019.103395

Di Francesco A, Di Foggia M, Jajc J, Gunde-Cimerman N, Baraldi E (2020b) Study of the efficacy of Aureobasidium strains belonging to three different species: A. pullulans, A. subglaciale, and A. melanogenum against Botrytis cinerea of tomato. Ann Appl Biol. https://doi.org/10.1111/aab.12627

Eckert JW, Ratnayake M (1994) Role of volatile compounds from wounded oranges in induction of germination of Penicillium digitatum conidia. Postharvest Pathol Mycotox 84:746-750. https://doi.org/10.1094/phyto-84-746

Fialho MB, Toffano L, Pedroso MP, Augusto F, Pascholati SF (2010) Volatile organic compounds produced by Saccharomyces cerevisiae inhibit the in vitro development of Guignardia citricarpa, the causal agent of citrus black spot. World J Microb Biot 26:925-932. https://doi.org/10.1007/s11274-009-0255-4

Friedman M, Henika PR, Mandrell RE (2003) Antibacterial activities of phenolic benzaldehydes and benzoic acids against Campylobacter jejuni, Escherichia coli, Listeria monocytogenes. J Food Prot 66:1811-1821. https://doi. org/10.4315/0362-028x-66.10.1811

Gabler M, Mansour MF, Smilanick JL, Mackey BE (2004) Survival of spores of Rhizopus stolonifer, Aspergillus niger, Botrytis cinerea and Alternaria alternata after exposure to ethanol solutions at various temperatures. J App Microbiol 96:1354-1360. https://doi.org/10.1111/j.1365-2672.2004.02280.x

Gostinčar C, Ohm RA, Kogej T, Sonjak S, Turk M, Zajc J, Zalar P, Grube M, Sun H, Han J (2014) Genome sequencing of four Aureobasidium pullulans varieties: biotechnological potential, stress tolerance, and description of new species. BMC Genom 15:549. https://doi.org/10.1186/1471-2164-15-549

Gostinčar C, Turk M, Zajc J, Gunde-Cimerman N (2019) Fifty Aureobasidium pullulans genomes reveal a recombining polyextremotolerant generalist. Environ Microbiol 21:3638-3652. https://doi.org/10.1111/1462-2920.14693

Gotor-Vila A, Teixidó N, Di Francesco A, Usall J, Ugolini L, Torres R, Mari M (2017) Antifungal effect of volatile organic compounds produced by Bacillus amyloliquefaciens CPA-8 against fruit pathogen decays of cherry. Food Microbiol 64:219-225. https://doi.org/10.1016/j.fm.2017.01.006

Kanchiswamy CN, Malnoy M, Maffei ME (2015) Chemical diversity of microbial volatiles and their potential for plant growth and productivity. Front Plant Sci 6:151. https://doi.org/10.3389/ fpls.2015.00151

Kachalkin A (2010) New data on the distribution of certain psychrophilic yeasts in Moscow oblast. Microbiology 79:840-844

Lesaffre E, Molenberghs G (1991) Multivariate probit analysis: a neglected procedure in medical statistics. Stat Med 9:13911403. https://doi.org/10.1002/sim.4780100907

Lichter A, Zutchy Y, Sonego L, Dvir O, Kaplunov T, Sarig P, BenArie R (2002) Ethanol controls postharvest decay of table grapes. Postharvest Biol Technol 24:301-308

Liu TT, Zhu LY, Zhang ZP, Huang H, Zhang ZD, Jiang L (2017) Protective role of trehalose during radiation and heavy metal stress in Aureobasidium subglaciale F134. Sci Rep 7:1-9. https ://doi.org/10.1038/s41598-017-15489-0

Lohmar FJ (1988) World geodetic system 1984 - geodetic reference system of GPS orbits. In: Groten E, Strauß R (eds) GPS-Techniques applied to geodesy and surveying. Lecture notes in earth sciences, vol 19. Springer, Berlin. https://doi.org/10.1007/BFb00 11360

Lurie S, Pesis E, Gadiyeva O, Feygenberg O, Ben-Arie R, Kaplunov T, Zutahy Y, Lich A (2006) Modified ethanol atmosphere to control decay of table grapes during storage. Postharvest Biol Technol 42:222-227. https://doi.org/10.1016/j.postharvbi o.2006.06.011

Mestre C, Rosa CA, Safar S, Libkind D, Fontenla S (2011) Yeast communities associated with the bulk-soil, rhizosphere and ectomycorrhizosphere of a Nothofagus pumilio forest in northwestern Patagonia, Argentina. FEMS Microb Ecol 78:531-541. https://doi.org/10.1111/j.1574-6941.2011.01183.x

Mitchell AM, Strobel GA, Moore E, Robison R, Sears J (2010) Volatile antimicrobials from Muscodor crispans, a novel endophytic fungus. Microbiol 156:270-275. https://doi.org/10.1099/ mic. 0.032540-0

Mounir R, Durieux A, Bodo E, Allard C, Simon JP, Achbani H, ElJaafari S, Douira A, Jijakli H (2007) Production, formulation and antagonistic activity of the biocontrol like-yeast Aureobasidium pullulans against Penicillium expansum. Biotechnol Lett 29:553. https://doi.org/10.1007/s10529-006-9269-2 
Parafati L, Vitale A, Restuccia C, Cirvilleri G (2015) Biocontrol ability and action mechanism of food-isolated yeast strains against Botrytis cinerea causing post-harvest bunch rot of table grape. Food Microbiol 47:85-92. https://doi.org/10.1016/j. fm.2014.11.013

Romanazzi G, Karabulot OA, Smilanick JL (2007) Combination of chitosan and ethanol to control postharvest gray mold of table grapes. Postharvest Biol Technol 45:134-140. https://doi. org/10.1016/j.postharvbio.2007.01.004

Strobel GA, Dirkse E, Sears J, Markworth C (2001) Volatile antimicrobials from Muscodor albus, a novel endophytic fungus. Microbiol 147:2943-2950. https://doi.org/10.1099/00221 287-147-11-2943

Zajc J, Gostinčar C, Cernoša A, Gunde-Cimerman N (2019) Stresstolerant yeasts: opportunistic pathogenicity versus biocontrol potential. Genes 10:42. https://doi.org/10.3390/genes10010042

Zajc J, Černoša A, Di Francesco A, Castoria A, De Curtis F, Lima G, Badri H, Jijakli H, Ippolito A, Gostinčar C, Zalar CP,
Gunde-Cimerman N, Janisiewicz WJ (2020) Variability of characteristics of Aureobasidium pullulans isolates exhibiting biocontrol activity against fruit decay pathogens. Fungal Gen Biol 10:1-13. https://doi.org/10.35248/2165-8056.20.10.163

Zalar P, Gostinčar C, de Hoog GS, Uršič V, Sudhadham M, GundeCimerman N (2008) Redefinition of Aureobasidium pullulans and its varieties. Stud Mycol 61:21-38. https://doi.org/10.3114/ sim.2008.61.02

Zhang D, Spadaro D, Garibaldi A, Gullino ML (2010) Efficacy of the antagonist Aureobasidium pullulans PL5 against postharvest pathogens of peach, apple and plum and its modes of action. Biol Control 54:172-180. https://doi.org/10.1016/j.biocontrol.2010.05.003

Publisher's Note Springer Nature remains neutral with regard to jurisdictional claims in published maps and institutional affiliations. 